\title{
Heavy Metal Accumulation In the Leaves, Stem and Root of the Invasive Submerged Macrophyte Myriophyllum spicatum L. (Haloragaceae): An Example of Kadın Creek (Mugla, Turkey)
}

\author{
Murat Yabanlı*, Aykut Yozukmaz and Fatma Sel \\ Faculty of Fisheries; Mugla Sitki Kocman University; Kotekli, Mugla - Turkey
}

\begin{abstract}
In this study, the existence of heavy metals such as chromium (Cr), arsenic (As), cadmium (Cd), mercury (Hg) and lead $(\mathrm{Pb})$ their distribution in the organs of plant and their bioaccumulation rates in water samples and Myriophyllum spicatum which were collected from the Kadin Creek in seasonal periods between 2011 and 2012 were analyzed. Heavy metal concentrations in the mineralized plant and water samples were determined with Inductive coupled plasma with mass spectroscopy (ICP-MS). Results showed the maximum heavy metal concentrations, in the root and minimum heavy metal concentrations, except chromium, in the stem. The distribution of heavy metals $\mathrm{As}, \mathrm{Cd}, \mathrm{Hg}$ and $\mathrm{Pb}$ was in the form of root > leaf > stem; the distribution of Cr was in the root > stem > leaf. There was a strong negative correlation between the suspended solid matter and heavy metal concentrations in the plant tissues. Heavy metal accumulation showed increase generally in fall. Heavy metals in the water were sorted as $\mathrm{Pb}>\mathrm{Cr}>\mathrm{As}>\mathrm{Hg}>\mathrm{Cd}$ by their mean concentrations. According to the factor data of bioconcentration, the order of heavy metal accumulation in the plant was $\mathrm{As}>\mathrm{Cr}>\mathrm{Pb}>\mathrm{Hg}>\mathrm{Cd}$.
\end{abstract}

Key words: Heavy metals, Myriophyllum spicatum, Kadın Creek.

\section{INTRODUCTION}

Myriophyllum spicatum L. (Eurasian watermilfoil) is a submerged perennial plant which is found naturally in the shallow water bodies whose depth is generally lower than $4.5 \mathrm{~m}$ in Europe, Asia and North Africa. It holds with its roots to the sediment in the water and its flowers grow afloat. Inflorescence and seed production are common. It can be found all the year round in the water (Aiken et al. 1979; Li et al. 2010).

Water pollution is one of the serious environmental problems originated from the overpopulation, urbanization, industrialization and ignorance (Satya et al. 2011). Unlike the organic materials, heavy metals which are considered as industrial contaminants do not degrade. Thus, they accumulate in the water, earth, deep sediment and in the living organisms. Contamination of the water with heavy metals is a serious concern in today's world (Miretzky et al. 2004). In natural aquatic ecosystems, metals are normally at the levels varying from nanogram to microgram in a liter. Recently, heavy metals' exceeding the carrying capacity of waters has caused some problems with regards to aquatic ecosystem balance (Ndimele and Jimoh 2011).

In aquatic system, where the input of pollutants is not continuous and they are thus get diluted, the analysis of plant tissues provides information

*Author for correspondence: myabanli@gmail.com 
about the quality of the system (Baldantoni et al. 2005). The use of macrophyte as biological indicator in monitoring the heavy metals has some advantages as they tolerate high concentrations of the heavy metals in the water their samplings are easy and individuals are big (Zhou et al. 2008). Due to their role as biological indicators for heavy metals and their capacity in refining the water from the contaminants, aquatic macrophytes have recently been a focus (Duman et al. 2009; Kara 2010; Fawzy et al. 2011).

In this study, the bioaccumulation of heavy metals such as $\mathrm{Cr}, \mathrm{As}, \mathrm{Cd}, \mathrm{Hg}$ and $\mathrm{Pb}$ in the roots, stem and leaves of Myriophyllum spicatum which were collected from the Kadın Creek in seasonal periods were analyzed. The specific goals were (1) to determine the heavy metal concentrations in the water and in different organs, (2) to determine the plant organs, which showed the highest bioaccumulation and (3) to assess the effect of the seasons on heavy metal concentrations.

\section{MATERIALS AND METHODS}

Kadın Creek is a meandering aquatic ecosystem whose depth is $6 \mathrm{~m}$ in some parts and whose length is $1700 \mathrm{~m}$ (Fig. 1). Water discharge in the outlet of Kadin Creek is approximately $700 \mathrm{~L} \mathrm{~h}^{-1}$. It is fed by the little streams during its journey towards the sea (Yusufoglu 2010). In the northern coast of the river, settlements are present. However, its southern coast is covered with the reeds and there are dense algae colonies in places. In addition to illegal waste disposal, excursion boats and fishing boats are significant causes of water pollution in this area (Demirak et al. 2011). Also, boat repair and dyeing works were being carried out around the studied creek.

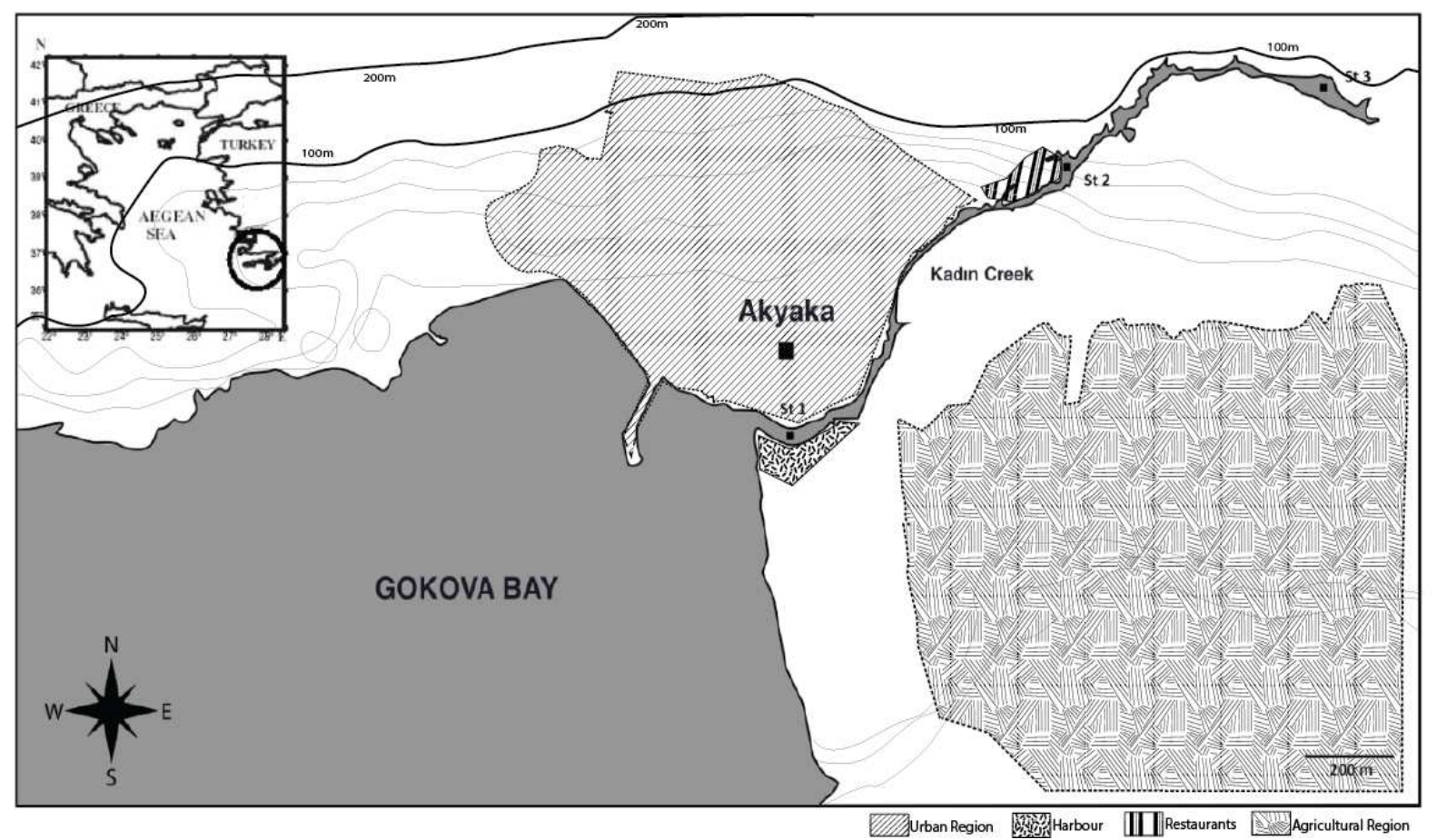

Figure 1 - Study area is located at N 37 $3^{\prime} 11^{\prime \prime}$ - E $28^{\circ} 19^{\prime} 48^{\prime \prime}$

Water quality parameters [Temperature, $\mathrm{pH}$, Total Dissolved Solids (TDS), Dissolved Oxygen (DO) and Conductivity] in study area were determined with YSI 550 brand multiparameter.

Water samples were taken from $10-15 \mathrm{~cm}$ under the surface water in seasonal periods into previously-washed 1 L-plastic containers and carried to laboratory in a freezer. The samples were filtered through membrane filter of pore size of $0.45 \mu \mathrm{m}$ and acidified with nitric acid $(65 \%$ Suprapur Merck) to $\mathrm{pH}<2.0$. These samples were stored in the refrigerator at about $4^{\circ} \mathrm{C}$ till the analysis. For the metals analysis, the samples were taken into $10 \mathrm{~mL}$ plastic acid-fast test tubes and determined by using ICP-MS (Agilent 7700x). 
The concentrations of suspended particulate matter (SPM) in the water samples were measured by filtering water samples $(\sim 1.000 \mathrm{~mL})$ through preweighed $0.45 \mu \mathrm{m}$ paper filters. The filters were dried at $105^{\circ} \mathrm{C}$ for $12 \mathrm{~h}$ and weighed and the weight difference was used to calculate the amount of suspended particulate matter in the samples (Onderka and Pekárová 2008).

The samples of $M$. spicatum were collected between 2011 and 2012 seasonally with random sampling from the Kadın Creek. Sampling was made from three different stations where the plants densely existed. Study area is shown in the Figure 1. The plants, which were botanized were put into polyethylene bags and taken to the laboratory. The lengths of the plants were between 20 and $23 \mathrm{~cm}$.

The samples of Eurasian watermilfoil, which were brought to laboratory were washed twice with distilled water (Human Power I Scholar UV trade marker water purification system) to clear them of periphyton and detritus. Then, its leaves stem and roots were dissected. Digestion process was carried out according to Sasmaz and Obek (2009). The plant samples were dried at $103^{\circ} \mathrm{C}$ for $24 \mathrm{~h}$ and the ash contents were determined by heating at $480^{\circ} \mathrm{C}$ for $4 \mathrm{~h}$. $\mathrm{HCl}(2.0 \mathrm{~mL}$, suprapur, $30 \%$, Merck), $\mathrm{HNO}_{3}(2.0 \mathrm{~mL}$, suprapur, 65\%, Merck) and $\mathrm{H}_{2} \mathrm{O}_{2}(2.0 \mathrm{~mL}$, suprapur, $30 \%$, Merck) were added to $1.0 \mathrm{~g}$ ash and the mixture was heated at $95^{\circ} \mathrm{C}$ hot plate for an hour. Then the overall volume was made to $50 \mathrm{~mL}$ with ultra pure water.

Heavy metal concentrations in the solubilized plant organs were determined with inductively coupled plasma-mass spectroscopy (ICP-MS, Agilent 7700x). Calibration solutions were prepared with $10 \mathrm{mg} \mathrm{L}^{-1}$ mix element standard stock solution (AccuTrace MES-21-1) and $10 \mathrm{mg} \mathrm{L} \mathrm{L}^{-1}$ mercury standard stock solution (AccuTrace MES-21-HG-1). Correlation coefficient values of calibration curves for $\mathrm{Cr}$, $\mathrm{As}$, $\mathrm{Cd}, \mathrm{Hg}, \mathrm{Pb}$ were 0.999 or better.

\section{Bioconcentration Factor}

Bioconcentration of any chemical by aquatic organisms is described with bioconcentration factor (Phetsombat et al. 2006). Bioconcentration factor (BCF) was calculated using the formula as below (Sadiq 1992).

$\mathrm{BCF}=$ Concentration of element in plant $/$ Concentration of element in water

\section{Validation of Method}

Whole Eurasian watermilfoil samples were spiked with heavy metals $(\mathrm{Cr}, \mathrm{As}, \mathrm{Cd}, \mathrm{Hg}$ and $\mathrm{Pb})$ for the recovery repeatability tests. Ten homogenized blanks and ten homogenized spiked samples were digested and analyzed using ICP-MS. The results were $95.07 \%$ for $\mathrm{Cr}, 96.59 \%$ for As, $97.80 \%$ for $\mathrm{Cd}, 92.58 \%$ for $\mathrm{Hg}$ and $93.06 \%$ for $\mathrm{Pb}$.

\section{Data Analysis}

Data analysis was carried out using the packaged SPSS software version 15.0 for statistical analysis and variance analysis. The relationship between the groups was determined with Tukey test. A level of 0.05 and 0.01 alpha were used to determine the significance and correlation, respectively. The significance was reported as $\mathrm{p}<0.05$ and $\mathrm{p}<0.01$ levels.

\section{RESULTS AND DISCUSSION}

The heavy metals were analyzed in 56 plant samples and 12 water samples. Water quality parameters determined during the study are shown in Table 1.The results of the analysis obtained from plant sampled were shown at Table 2. The distribution of elements by their concentrations in plant organs was as root > leaf > stem except chromium. The distribution of chromium was as root > stem > leaf. This might be because chromium showed low mobility ability in its transport from the root to green parts of the plant (Shewry and Peterson 1974).

Table 1 - Mean values of water quality parameters found at study site.

\begin{tabular}{|c|c|c|c|c|}
\hline & Winter & Spring & Summer & Autumn \\
\hline $\begin{array}{l}\text { Temperature } \\
\left({ }^{\circ} \mathbf{C}\right)\end{array}$ & 14.81 & 14.88 & 16.71 & 15.03 \\
\hline $\begin{array}{l}\text { Conductivity } \\
\left(\mu \mathrm{S} \mathrm{cm}^{-1}\right)\end{array}$ & 5602 & 5200 & 5891 & 5714 \\
\hline TDS $\left(\mathrm{mg} \mathrm{L}^{-1}\right)$ & 382 & 338 & 412 & 396 \\
\hline $\begin{array}{l}\text { Suspended } \\
\text { Solid Matter } \\
\left(\mathrm{g} \mathrm{L}^{-1}\right)\end{array}$ & 0,004583 & 0,004055 & 0,004567 & 0,004751 \\
\hline Salinity (ppm) & 3.22 & 2.86 & 3.37 & 3.28 \\
\hline $\begin{array}{l}\text { Dissolved } \\
\text { Oxygen }\left(\mathrm{mg} \mathrm{L}^{-1}\right)\end{array}$ & 8.61 & 8.42 & 7.89 & 8.12 \\
\hline pH & 7.03 & 8.10 & 7.24 & 7.12 \\
\hline
\end{tabular}


Table 2 - Mean concentration ( \pm standard error) of studied heavy metals in the different organs of $M$. spicatum $\left(\mathrm{mg} \mathrm{kg}^{-1} \mathrm{dw}\right)$.

\begin{tabular}{cccc}
\hline & Leaf & Stem & Root \\
\hline $\mathbf{C r}$ & $4.59 \pm 0.97$ & $5.34 \pm 1.07$ & $9.07 \pm 2.24$ \\
As & $1.13 \pm 0.29$ & $0.32 \pm 0.11$ & $15.30 \pm 3.06$ \\
$\mathbf{C d}$ & $0.06 \pm 0.02$ & $0.04 \pm 0.02$ & $0.36 \pm 0.07$ \\
$\mathbf{H g}$ & $0.71 \pm 0.30$ & $0.11 \pm 0.04$ & $1.18 \pm 0.16$ \\
$\mathbf{P b}$ & $6.25 \pm 0.94$ & $3.05 \pm 0.43$ & $17.04 \pm 2.21$ \\
\hline
\end{tabular}

The $\mathrm{p}$ alfa values between the plant organs for the heavy metals are presented in Table 3 . There was a statistically significant difference between the root and stem and between the leaf and root arsenic, cadmium and lead $(\mathrm{p}<0.05)$. While there was a statistically significant difference between the root and stem for mercury $(\mathrm{p}<0.05)$, there was not any statistically significant difference for chromium in plant organs $(p>0.05)$. Also, none of the studied heavy metals showed any statistically significant difference with regard to their distribution between the leaf and stem $(\mathrm{p}>0.05)$.

Table 3 - $\mathrm{P}$ value relation between plant organs in terms of heavy metals.

\begin{tabular}{|c|c|c|c|c|c|}
\hline & $\mathrm{Cr}$ & As & Cd & $\mathrm{Hg}$ & $\mathbf{P b}$ \\
\hline $\begin{array}{c}\text { Leaf } \\
- \\
\text { Stem }\end{array}$ & 0.909 & 0.891 & 0.939 & 0.211 & 0.109 \\
\hline $\begin{array}{c}\text { Leaf } \\
- \\
\text { Root }\end{array}$ & 0.74 & $0.000 *$ & $0.000^{*}$ & 0.476 & $0.000 *$ \\
\hline $\begin{array}{c}\text { Root } \\
- \\
\text { Stem }\end{array}$ & 0.159 & $0.000 *$ & $0.000^{*}$ & $0.025 *$ & $0.000 *$ \\
\hline
\end{tabular}

The analyses of the seasonal distributions of heavy metals in the organs were showed a statistically significant difference for all the heavy metals in the $\operatorname{root}(\mathrm{p}=0.253, \mathrm{p}=0.111 ; \mathrm{p}<0.05)$ and also in the leaves and stem except for mercury $(\mathrm{p}<0.05)$. Guilizzoni (1991) observed that the heavy metals in the plants showed seasonal changes. In this study, the studied heavy metals underwent seasonal change and there was an increase in heavy metal concentrations generally in spring. The reason was that spring growth was characterized by a rapid uptake of nutrients and trace elements (Duman et al. 2006). Grudnik (2010) found similar results as of this study that the concentrations of heavy metals such as $\mathrm{Cr}$, As and $\mathrm{Pb}$ in $M$. spicatum plant were more in spring than any other season.

According to BCF data, the uptake order of heavy metals in the whole plant was $\mathrm{As}>\mathrm{Cr}>\mathrm{Pb}>\mathrm{Hg}$ $>\mathrm{Cd}$. The BCF values are shown in Figure 2.

Results of heavy metal analysis of waters are shown in Table 4. The mean heavy metal concentrations in the water could be arranged in order as $\mathrm{Pb}>\mathrm{Cr}>\mathrm{As}>\mathrm{Hg}>\mathrm{Cd}$. Seasonal distribution of all the heavy metals in the water showed statistically significant difference $(\mathrm{p}<0.05)$.

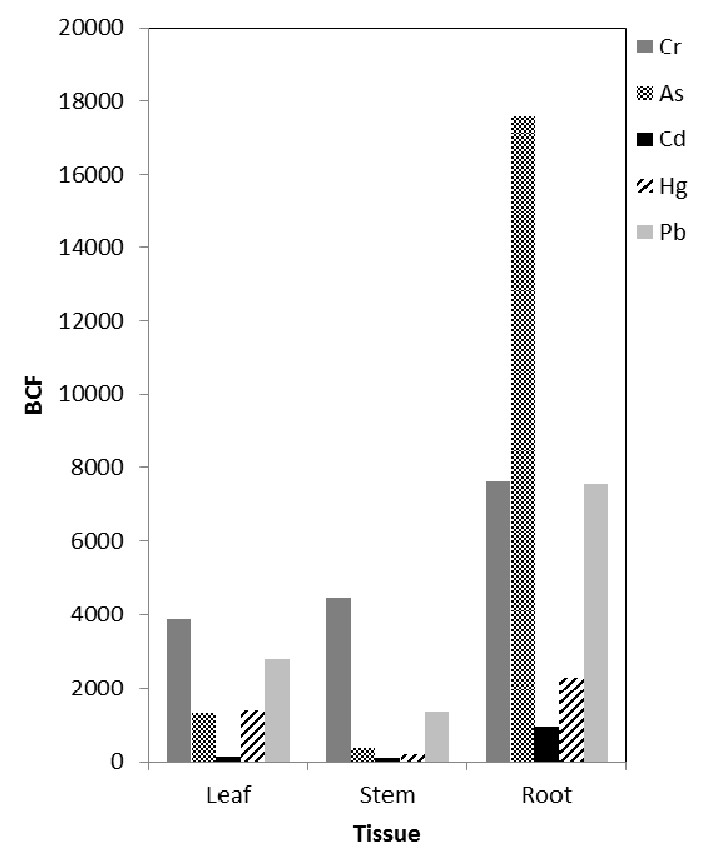

Figure 2 - Bioconcentration Factor (BCF) by extense rates as to organs.

Table 4 - The mean ( \pm standard error) heavy metal concentrations in the waters $\left(\mu \mathrm{g} \mathrm{L}^{-1}\right)$.

\begin{tabular}{cccccc}
\hline & $\mathbf{C r}$ & $\mathbf{A s}$ & $\mathbf{C d}$ & $\mathbf{H g}$ & $\mathbf{P b}$ \\
\hline Winter & $1.60 \pm 0.02$ & $0.81 \pm 0.01$ & $0.01 \pm 0.003$ & $1.91 \pm 0.01$ & $1.17 \pm 0.01$ \\
Spring & $2.32 \pm 0.03$ & $1.03 \pm 0.05$ & $1.29 \pm 0.04$ & $0.14 \pm 0.01$ & $2.12 \pm 0.02$ \\
Summer & $0.84 \pm 0.02$ & $0.75 \pm 0.01$ & $0.11 \pm 0.01$ & $0.01 \pm 0.003$ & $2.42 \pm 0.03$ \\
Autumn & $0.01 \pm 0.003$ & $0.90 \pm 0.01$ & $0.10 \pm 0.01$ & $0.01 \pm 0.003$ & $3.28 \pm 0.02$ \\
Average & $1.19 \pm 0.26$ & $0.87 \pm 0.03$ & $0.38 \pm 0.16$ & $0.52 \pm 0.24$ & $2.25 \pm 0.23$ \\
\hline
\end{tabular}


Suspended solid matter consists of various organic and inorganic matters. Most of them hold onto the surfaces of particles in water. Organic matters in the water have the ability of binding the heavy metals (Sklodowski et al. 2006; Balkis et al. 2010). In this study, as shown in Figure 3; when suspended solid matter increased, the amount of heavy metal in the root, stem and leaf decreased, or vice versa. In other words, there was a strong negative correlation between the suspended solid matter in the water and heavy metal concentrations in the plant tissues. The highest negative correlation was in the roots and correlation coefficients were as $-0.993,-0.996,-0.998$ and $0.997(\mathrm{p}<0.01)$ for the winter, spring, summer and autumn, respectively.

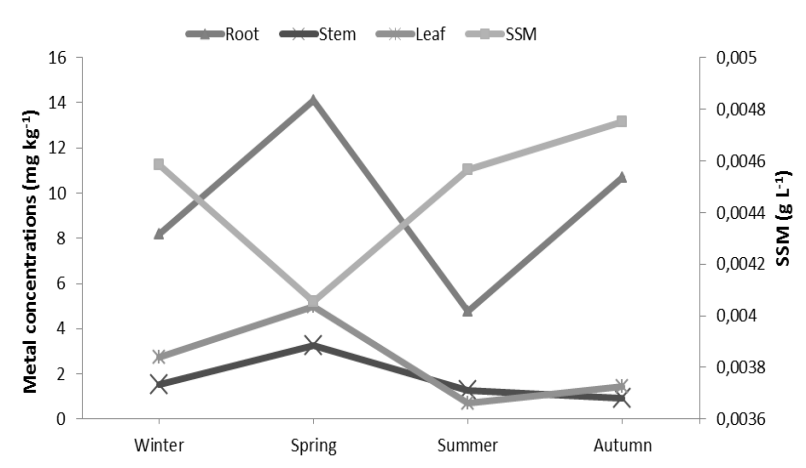

Figure 3 - Change of total mean heavy metal concentrations in root, stem, and leaf with regard to suspended solid matter (SSM), seasonally.

Yucel et al. (2010) monitored heavy metals in the River Porsuk by using M. spicatum as an indicator. The mean lead concentrations obtained from the stem and the leaves of the plant were 61.50 and $59.63 \mathrm{mg} \mathrm{kg}^{-1}$, respectively. The mean cadmium concentrations were 0.81 and $1.81 \mathrm{mg} \mathrm{kg}^{-1}$, respectively. The mean lead (stem 3.05, leaf 6.25 $\mathrm{mg} \mathrm{kg}^{-1}$ ) and cadmium (stem 0.04 , leaf $0.06 \mathrm{mg}$ $\mathrm{kg}^{-1}$ ) concentrations obtained from the stem and the leaves of the plant in this study were considerably less than the lead and cadmium values measured in the plants, which were collected from the River Porsuk. A study on cadmium biosorption ability of species $M$. spicatum and $M$. triphyllum was researched, it showed that both of the species could bioaccumulate cadmium effectively (Sivaci et al. 2004). In another study, M. spicatum showed the accumulation of lead from water and the maximum adsorption $46.49 \mathrm{mg} \mathrm{kg}^{-1}$ (Keskinkan et al. 2003). The lead adsorption capasities of $M$. spicatum and Ceratophyllum demersum were compared and it was observed that $M$. spicatum had better adsorption capacity than $C$. demarsum (Keskinkan et al. 2007). In a study in which cadmium and lead bioaccumulation in Salvinia cucullata plant was analyzed, it was seen that the contents of cadmium and chromium were much more in the roots than in the leaves, as found in this study (Phetsombat et al. 2006).

Samecka-Cymerman and Kempers (2004) studied the toxic metals in the species of M. spicatum and Potamogeton pectinatus near a copper casting facility in Legnica, Poland. Considering the highest metal concentrations they obtained, it was found that cadmium and lead were in the higher concentrations in $M$. spicatum and chromium was in the higher concentration in $P$. pectinatus (cadmium: M. spicatum $8.8 \mathrm{mg} \mathrm{kg}^{-1}$, P. pectinatus $1.5 \mathrm{mg} \mathrm{kg}^{-1}$; lead: $M$. spicatum $850 \mathrm{mg} \mathrm{kg}{ }^{-1}, P$. pectinatus $237 \mathrm{mg} \mathrm{kg}^{-1}$; chromium: M. spicatum $1.9 \mathrm{mg} \mathrm{kg}^{-1}$, P. pectinatus $2.7 \mathrm{mg} \mathrm{kg}^{-1}$ ). The stems of the plants showed considerably higher chromium, cadmium and lead (5.34, 0.04, $3.05 \mathrm{mg}$ $\mathrm{kg}^{-1}$ respectively) than the results obtained from the stem in this study. Baldantoni et al. (2011) analyzed the distribution of chromium in two aquatic plants (Phragmites communis and Najas marina). They found higher chromium concentrations in the roots than in the green parts of the plant, as in this study.

Arsenic, one of the deadly toxic elements, is widely distributed in the aquatic systems. In addition, the agricultural and industrial effluent discharges also cause arsenic contamination in natural waters (Azizur Rahman and Hasegawa 2011). Li et al. (2011) studied on arsenic uptake in aquatic plants and they deduced that arsenic was present in order as root tissue > root surface > stem tissue and the highest arsenic accumulation rate was found in the root. This study also found the highest arsenic concentration $\left(15.30 \mathrm{mg} \mathrm{kg}^{-1}\right)$ in the root and the lowest arsenic concentration $\left(0.32 \mathrm{mg} \mathrm{kg}^{-1}\right)$ in the stem. Robinson et al. (2005) detected $2960 \mathrm{mg} \mathrm{kg}^{-1}$ arsenic in M. propinquum., which was much higher than the highest concentration obtained in this study.

Thompson-Roberts et al. (1999) analyzed the mercury concentrations in four aquatic plants (Myriophyllum spicatum, Nuphar variegatum, Elodea canadensis and Potamogeton crispus) in the St. Lawrence River. N. variegatum did not 
bioaccumulate mercury and the highest mercury bioaccumulation was seen in $M$. spicatum. The highest value $\left(0.24 \mathrm{mg} \mathrm{kg}^{-1}\right)$ obtained from $M$. spicatum was lower than the highest mean mercury concentration (root $1.18 \mathrm{mg} \mathrm{kg}{ }^{-1}$ ) obtained in this study. Similarly, the mean mercury concentration $\left(0.03 \mathrm{mg} \mathrm{kg}^{-1}\right)$ obtained from M. spicatum by Fontanella et al. (2009) in the Lake Candia (Italy) was notably lower than the mercury values obtained in this study. Soto et al. (2011) found that mercury concentration in submerged species (M. spicatum and Ceratophyllum demersum) was at least 40 times more than mercury concentration in the contaminated area. Similarly, mercury concentration in the root of the plant was 2269.23 (biological concentration factor) times more than in the water in this study.

\section{CONCLUSION}

The heavy metals were distributed in different organs in the plant in different amounts. The highest heavy metal accumulation was in the roots and the lowest accumulation was in the stem (root $>$ leaf $>$ stem). However, for chromium the order was as root > stem > leaf. There was an efficient negative correlation between the SSM and heavy metal levels in the different parts of plant in each season. The heavy metal bioaccumulation in the plant was maximum in spring, because plant development accelerated in spring and nutrient/metal uptake also increased. Heavy metals' order for the BCF values were as As $>\mathrm{Cr}$ $>\mathrm{Pb}>\mathrm{Hg}>\mathrm{Cd}$ in the Kadın Creek. The plant accumulated arsenic in the water particularly in its roots. Thus, $M$. spicatum could be used effectively as a bioindicator in monitoring the water quality biologically in terms of heavy metals.

\section{REFERENCES}

Aiken SG, Newroth P, Wile I. The biology of Canadian weeds (Myriophyllum spicatum L.). Can J Plant Sci. 1979; 59: 201-245.

Azizur RM, Hasegawa H. Aquatic arsenic: Phytoremadiation using floating macrophytes. Chemosphere. 2011; 83: 633-646.
Baldantoni D, Maisto G, Bartoli G, Alfani A. Analyses of three native aquatic plant species to assess spatial gradient of lake trace element contamination. Aquat Bot. 2005; 83: 48-60.

Baldantoni D, Alfani A, Di Tommasi P, Bartoli G, De Santo AV. Assessment of macro and microelement accumulation capability of two aquatic plants. Environ Pollut. 2011; 130: 149-156.

Balkis N, Aksu A, Okuş E, Apak R. Heavy metal concentration in water, suspended matter, and sediment from Gökova Bay, Turkey. Envıron Monit Assess. 2010; 167: 359-370.

Demirak A, Yılmaz HA, Keskin F, Şahin Y, Akpolat O. Investigation of heavy metal content in the suspended particulate matter and sediments of inner Gokova Bay and creeks. Environ Monit Assess. 2011; 184:71137124.

Duman F, Obali O, Demirezen D. Seasonal changes of metal accumulation and distribution in shining pondweed (Potamogeton lucens). Chemosphere. 2006; 65: 2145-2151.

Duman F, Leblebici Z, Aksoy A. Growth and bioaccumulation characteristics of watercress (Nasturtium officinale R.BR.) exposed to cadmium, cobalt and chromium. Chem Spec Bioavailab. 2009; 21: 257-265.

Fawzy MA, El-sayed Badr N, El-Khatib A, Abo-ElKassem A. Heavy metal biomonitoring and phytoremediation potentialities of aquatic macrophytes in River Nile. Environ Monit Assess. 2011; 184(3):1753-1771.

Fontanella MC, Ravera O, Beone GM, Riccardi N, Cattani I. Mercury distribution in the main compartments of the eutrophic Lake Candia (Northern Italy). J Limnol. 2009; 68: 352-358.

Grudnik ZM. Seasonal changes in the concentration of some trace elements in macrophyte shoots. Acta Biol Slo. 2010; 53: 55-61.

Guilizzoni P. The role of trace elements and toxic materials in the physiological ecology of submersed macrophytes. Aquat Bot. 1991; 41: 87-109.

Kara Y. Bioaccumulation of nickel by aquatic macrophytes. Desal Water Treat. 2010; 19: 325-328.

Keskinkan O, Goksu MZL, Yuceer A, Basibuyuk M, Forster CF. Heavy metal adsorption characteristics of a submerged aquatic plant (Myriophyllum spicatum). Process Biochem. 2003; 39: 179-183.

Keskinkan O, Goksu MZL, Yuceer A, Basibuyuk M. Comparison of the adsorption capabilities of Myriophyllum spicatum and Ceratophyllum demersum for zinc, copper and lead. Eng Life Sci. 2007; 7: 192-196.

Li G, Xue P, Yan C, Li Q. Copper biosorption by Myriophyllum spicatum: Effects of temperature and pH. Korean J Chem Eng. 2010; 27: 1239-1245. 
Li H, Ye ZH, Wei ZJ, Wong MH. Root porosity and radial oxygen loss related to arsenic tolerance and uptake in wetland plants. Environ Pollut. 2011; 159: 30-37.

Miretzky P, Saralegui A, Cirelli AF. Aquatic macrophytes potential for the simultaneous removal of heavy metals (Buenos Aires, Argentina). Chemosphere. 2004; 57: 997-1005.

Ndimele PE, Jimoh AA. Water hyacinth (Eichhornia crassipes (Mart.) Solms.) in phytoremediation of heavy metal polluted water of Ologe Lagoon, Lagos, Nigeria. Res J Environ Sci. 2011; 5: 424-433.

Onderka M, Pekárová P. Retrieval of suspended particulate matter concentrations in the Danube River from Landsat ETM data. Sci Total Environ. 2008; 397: 238-243.

Phetsombat S, Kruatrachue M, Pokethitiyook P, Upatham S. Toxicity and bioaccumulation of cadmium and lead in Salvinia cucullata. J Environ Biol. 2006; 27: 645-652.

Robinson B, Marchetti M, Moni C, Schroeter L, van den Dijssel C, Milne G, Bolan N, Mahimairaja S. Arsenic accumulation by aquatic and terrestrial plants. In: Naidu R, Smith E, Owens G, Bhattacharya P, Nadebaum P. (Eds.), Managing Arsenic in the Environment: From Soil to Human Health. CSIRO, Collingwood, Victoria, 2005; pp. 235-247.

Sadiq M. Forest fire ash impact on micro- and macroalgae in the receiving waters of the east coast of South Korea. Mar Pollut Bullet. 1992; 45: 203209.

Samecka-Cymerman A, Kempers AJ. Toxic metals in aquatic plants surviving in surface water polluted by copper mining industry. Ecotox Environ Safe. 2004; 59: 64-69.

Sasmaz A, Obek E. The accumulation of arsenic, uranium, and boron in Lemna gibba L. exposed to secondary effluents. Ecol Eng. 2009; 35: 1564-1567.

Satya N, Ojha CSP, Mishra SK, Chaube UC, Sharma PK. Cadmium and chromium removal by aquatic plant. Int J Environ Sci. 2011; 1: 1297-1304.
Shewry PR, Peterson PJ. The uptake and transport of chromium by Barley seedlings (Hordeum vulgare L.). Planta. 1974; 132: 209-214.

Sivaci ER, Sivaci A, Sökmen M. Biosorption of cadmium by Myriophyllum spicatum L. and Myriophyllum triphyllum orchard. Chemosphere. 2004; 56: 1043-1048.

Sklodowski P, Maciejewska A, Kwiatkowska J. The effect of organic matter from brown coal on bioavailability of heavy metals in contaminated soils. In: Twardowska I, Allen HE, Häggblom MM, Stefaniak S. Editors. Soil and water pollution monitoring, protection and remediation. Netherland NATO Science Series. Springer. 2006; p. 299-307.

Soto DX, Roing R, Gacia E, Catalan J. Diffirential accumulation of mercury and other trace metals in the food web components of a reservoir impacted by a chlor-alkali plant (Flix, Ebro River, Spain): Implications for biomonitoring. Environ Pollut. 2011; 159: 1481-1489.

Thompson-Roberts ES, Pick FR, Hall GEM. Total Hg in water, sediment, and four species of aquatic macrophytes in the St. Lawrence River, near Cornwall, Ontario. J Great Lakes Res. 1999; 25: 294304.

Yucel E, Edirnelioğlu E, Soydam S, Çelik S, Çolak G. Myriophyllum spicatum (spiked water-milfoil) as a biomonitor of heavy metal pollution in Porsuk Stream/Turkey. BioDiCon. 2010; 3: 133-144.

Yusufoglu A. A critical review of the tools and techniques used in coastal planning: Case study Mugla-Gokova special environmental protection area [Ms thesis]. Ankara, Turkey: The Graduate School of Natural and Applied Sciences of Middle East Technical University; 2010.

Zhou Q, Zhang J, Fu J, Shi J, Jiang G. Biomonitoring: An appealing tool for assessment of metal pollution in the aquatic ecosystem. Anal Chim Acta. 2008; 606: 135-150. 